\title{
IMAM ZARKASYI'S MODERNIZATION OF PESANTREN IN INDONESIA (A Case Study of Darussalam Gontor)
}

\author{
Hamid Fahmy Zarkasyi \\ University of Darussalam Gontor \\ hfzark@unida.gontor.ac.id
}

\begin{abstract}
This paper aimed at elaborating Imam Zarkasyi's thought and practices in modernizing the traditional Islamic education called Pesantren. The method employed for this study is descriptive and explanatory research. The data is collected from documents such as books, research article and brochure, and from author observation from time to time. This paper identifies that the educational thought and experiences of Imam Zarkasyi as well as his religious inclination played an important role in his modernization of pesantren. The research also found that Imam Zarkasyi's thought and practices in modernizing Pesantren system started from his serious observation and evaluation as well as his appreciation of traditional pesantren and madrasah system of education. The step taken by Imam Zarkasyi to modernize the education system was by integrating pesantren and madrasah system. In modernizing curriculum Imam Zarkasyi integrated the formal, non-formal and informal education utilizing pesantren environment. Students are taught not only subjects on religion and general sciences in the classroom, butalso obtaining morality, mental and job skill
\end{abstract}


education and other values in pesantren tradition within a well-designed informal and non-formal education. Finally, to ensure the sustainability of pesantren Imam Zarkasyi changed the status of Pesantren institution from personal ownership into public property by way Waqf. The thought had been practically implemented successfully in secondary level and now the Waqf Board started to implement the practice at university level.

Keywords: Pesantren, System, Integration, Educational Thought.

\section{A. Introduction}

In the early $20^{\text {th }}$ century, no Pondok or pesantren in south East Asia that deserved to hold the epithet of "modern" except Darussalam Gontor. In fact, the term "modern" was given by society due to its distinctive nature for it was neither like traditional Pondok nor ordinary modern school institution. The earliest research that identified the modernity of Darussalam Gontor was conducted by Lance Castle (Castles, L. 1966). Number of more serious research, subsequently appeared in the form Master thesis and Ph.D dissertation as well as research articles. Although the idea of modernization had started from its early inception in 1926 by the three brothers, but the establishment of secondary level (Kulliyatul Muallimin al-Islamiyah) by Imam Zarkasyi in 1936 suggested that the large-scale of modernization had started from this point. This fact might be the reason why some researchers exclusively depict Imam Zarkasyi's thought in the modernization of pesantren, but others portray Darussalam Gontor as an established modern Pondok without tracing it from Imam Zarkasyi's thought.

Those who dissect Imam Zarkasyi's thought of modernization had conducted in cursory manner or in partial 
approaches. Buchory, for example who in his final analysis inferred that Imam Zarkasyi's modernization of pesantren brought about new model of pesantren, approached the modernization only from educational and institutional system. (Bukhory, 2016: 259-272). Purnama, who elaborated Imam Zarkasyi's modernization only focus on the transformation of Islamic education which was more about the development of pesantren Gontor in brief from various angle since early inception until the present situation (Purnama, 2013, 100128). Another research on the thought of Imam Zarkasyi on modern Pondok was carried out by Mulyasari, who mentioned the idea of modernization in so many points in brief that one can hardly find the modernization of the whole system. (Mulyasari 2016: 31-62). Another research that deals with modernization of pesantren at Gontor was conducted by Iqbal who emphasized on Gontor transformation towards modernity. Although he also did not mention specifically the name of Imam Zarkasyi in the title, but the fact his delineation refers mostly to the idea of Imam Zarkasyi. Unlike the previous this research had comprehensively described all aspect of modern Pondok of Gontor, yet the focal point of modernization had not been delineated systematically. (Iqbal, 2017: 141-174).

Some other research that focus on certain aspect of Imam Zarkasyi's thought could be contributive for delineating more comprehensive idea of modernization. Nuriz for example studied Imam Zarkasyi's thought on character education in comparison with al-Zarnuji, which is a part of modernization. (Nuriz \& Awang, 2017: 46-59). In the same topic Mu'minah portrayed Imam Zarkasyi's thought on character building in comparison with Ibn Miskawayh. Here he depicts the character building within the modern system of pesantren that consist of education system, 
curriculum and moral education, yet this modernity is described only in cursory manner. (Mu'minah, 2015: 100-133). Similarly, Dacholfany, carried out his research on the style of leadership and its impact of character education at Gontor, but he does not trace the idea of Imam Zarkasyi, let alone his whole concept of modernization. (Dacholfany, 2015: 447 - 464). In line with Dacholfany, Yuliati delineated the modern system of Gontor with special emphasis on leadership training (Yuliati, 2015: 85-110).

Yapono also studied only on one particular aspect of Imam Zarkasyi's modernization of curriculum, namely hidden curriculum within informal and non-formal education in the system. He successfully proved its modernity from modern theory of education (Yapono, 2015, 291-312). The same issue as that of Yapono was carried out by Alhamuddin, but he did not mention Imam Zarkasyi specifically in the title of his paper and without referring to modern theory of education (Alhamuddin, 2018: 2540-7619). Still on the issue of curriculum Rofiq highlighted Imam Zarkasyi's idea on the integration of knowledge in curriculum, but he did not emphasize on the idea of modernization. (Rofiq, 2018, pp.313-346).

So far there was no significant research that deals with the thought of Imam Zarkasyi on those three crucial aspects in systemic manner. This work is aimed at disclosing the thought of Imam Zarkasyi in modernizing traditional pesantren by introducing modern systems and maintaining traditional values. The elaboration starts from his evaluation on traditional system of pesantren, from which he modernized gradually three pivotal aspects of pesantren namely: educational, curricular and institutional system.

This is descriptive and explanatory research that describes systematically Imam Zarkasyi's thought and praxis in 
modernizing the most important aspects of pesantren. The data is collected from documents such as books, research article and brochure as well as from observation which was done from time to time. The researcher verifies, classifies the facts and interpret them all in term of modernity.

\section{B. Brief Biographical Background}

Imam Zarkasyi was born on 21 March 1910 in small village atPonorogo district, East Java, Indonesia. His genealogical tree can be authentically traced over centuries through the Muslim preachers and educators of Java, particularly through the family of the most well-known pondok or pesantren in eighteenth century, named Tegalsari. Located about three kilometers away from Gontor, Tegalsari was a big and renowned Islamic education institution in Java. It was founded by Kiai Ageng Muhammad Besari, a descendant of the royal family of Majapahit, and became the school of the elite family of Java (Dasuki, 1960, p. 15). However, ordinary people were also eligible to study in it. Muhammad Besari was succeeded by his son Kiai Ageng Anom Besari and subsequently by his grandson Kiai Ageng Hasan Besari.

Zarkasyi's father, Santoso was the grandson of Raden Muhammad Hadikusumo Sulaiman Djamaluddin, the royal family of Kasepuhan (Kingdom) of Cirebon. Historically, RM. Sulaiman Djamaluddin the son in law and the outstanding disciple of Kiai Khalifah (the successor of Kiai Ageng Anom Besari), was awarded authority to found pesantren apart from Tegalsari. With his fortyone (41) students he established a new pesantren at Gontor village, and it grew into a prominent pesantren during that time. However, the pesantren gradually deteriorated and in its third generation it really declined. It was under the leadership of Kiai Santoso that Gontor became the old-dying pondok or pesantren. 
The young Imam Zarkasyi and his other two elder brothers witnessed the situation and started thinking on how to revive the dead pesantren that was the legacy of their ancestors. The idea of reviving the dead school was already playing in the mind of Imam Zarkasyi when he began his early education. He began his formal primary education at a village, neighboring Gontor.

Following his family tradition, he also applied to study in the Pondok or Pesantren to study the classical books such as Ta'limmu al-Muta'alim, as-Sullam, Safinatun-najah, and Taqrīb. So, he spent the whole evening and night at the Pesantren, while he attended the primary school in the morning. After three years he graduated from elementary school and he proceeded for another three years (Koentjaraningrat, 1982, p. 409) of secondary education in a school named Sekolah Ongko Loro (Vervolkschool) at Jetis, another village in Ponorogo district and completed it in 1925. For the sake of his religious education he moved to another Pesantren closer to his secondary school, named Pesantren Josari, which was headed by a teacher-scholar who graduated from Tegalsari. Upon completion of his secondary education, he continued his study in Solo, Jawa Tengah, about 150 miles from Gontor. In this city, Zarkasyi attended three education institutions simultaneously, which are: Pesantren Jamsaren (at night) (Panitia Penulis Riwayat Hidup Dan Perjuangan K.H. Imam Zarkasyi, 1996, pp. 18-24), Madrasah Arabiyyah Islamiyah (in the morning ) and Madrasah Manbaul Ulum (in the afternoon).

At Jamsaren Zarkasyi studied some books in the real traditional system of Pesantren, while at Manbaul Ulum he experienced modern classical system of education where specialized teacher on various subjects taught students in front of the class with modern method of teaching. The method was 
so attractive that the number of students from the elite family who attended this madrasah increased and later, a few became prominent Indonesian Ulama. Imam Zarkasyi not only learned various subjects from these pesantren and madrasah but also observed their educational practices. The most inspiring place for him was Madrasah Arabiyyah Islamiyah, especially under the tutelage of Ustadh Muhammad Oemar al-Hasyimi, a Muslim scholar and political figure from Tunisia. Imam Zarkasyi learned directly and personally from him about many things, especially about the philosophy of life, Arabic language and methods of Islamic education.

Upon the completion of his studies in the three educational institutions, in 1930, Imām Zarkasyi planned to further his study at al-Azhar University in Egypt, but due to some unavoidable reasons, he failed to do so. He then followed the suggestions of his teacher, al-Hasyimi to study at a madrasah where its teachers were graduates of al-Azhar or Dar-ul-Ulum, Cairo. So, he went to West Sumatra, the renowned place of the tajdid movement in Indonesia. He attended Sumatera Thawalib, Padang Panjang, where he studied social and natural sciences, English and Dutch language for two years (Panitia Penulis Riwayat Hidup Dan Perjuangan K.H. Imam Zarkasyi, 1996, p. 29). In 1932 he registered at the Normal Islamic School in the same city. This school was led by Dr. Mahmud Yunus, a graduate of Dar-ul-Ulum, Cairo and an expert on Islamic education in Indonesia (Panitia Penulis Riwayat Hidup Dan Perjuangan K.H. Imam Zarkasyi, 1996, p. 30). Some regarded Thawalib and Normal Islamic School as institutions of higher education, since these schools were attended only by graduates of secondary schools, yet no university degree was awarded to the students due to the colonial policy. It was from these two education institutions 
that Imam Zarkasyi learned a lot about the new system and method of Islamic education, especially the teaching methods of Arabic and English.

Imam Zarkasyi graduated from Normal Islamic School in 1935. Due to his outstanding achievement, his teacher Mahmud Yunus requested him to become a headmaster at a newly established school in Padang Sidempuan, Tapanuli in North Sumatera. He successfully managed the school but since his two brothers needed him to help establish a new system of Islamic education, he could only work for about one year. In short, after spending 10 years studying, he returned to his village in 1936 and established a new education program named Kulliyatu-l-Mu'allimin Al-Islamiyah (Teacher Training School) at the pesantren, which was initiated by his elder brother Ahmad Sahal in 1926.

Apart from his attempt to revive and renew the pesantren system of education, Imam Zarkasyi played his role in the struggle for Indonesia during the colonial period and after the independence. While being active as the director of Kulliyatul Mu'allimin al-Islamiyah, he also contributed through various positions in the government administration. Some of his positions in education activities were the followings: 1) Head of a Section (now department) for Islamic Education Affairs at the Ministry of Religious Affairs, 1946 2) Chairman of a Team for the Construction of Religious Education Curriculum at Elementary Schools, at the Ministry of Education, 19511953. 3) Chairman of the Council for Religious Education Supervision, the Ministry of Religious Affairs, 1953. 4) The chairman of Persatuan Guru Islam Indonesia, (the Association of Indonesian Muslim Teachers) in 1948-1955. 5) Chairman of Majelis Pertimbangan dan Pengembangan Pendidikan Agama, MP3A (Advisory Council for the Development of 
Religious Education) the Ministry of Religious Affairs, 1953 until his death in 1985. 6) Member of Dewan Perancang Nasional- Depernas, (Council for National Plan), since 1959. 7) Member of the Education Research Committee, Ministry of Education in 1946. 8) One of the founders of Indonesian Islamic University (UII) Yogyakarta. 9) The Founder and Director of Kulliyatul Muallimin al-Islamiyah. 10) The Rector of Darussalam Institute of Education (IPD) Gontor.

\section{His Religious inclination}

Elaborating Imam Zarkasyi's religious thought here is quite significant, for it will imply on his concept and practice of education. One of the most important thoughts of Imam Zarkasyi on religious issues is the doctrine of theology. This doctrine is written in his book Ushuluddin 'Ala Madzhab Ahlis-Sunnah wal-l-Jama'ah (Doctrines of the Religion according to the School of Ahli-s-Sunnah wal-l-Jama'ah). The book was written for the students and was claimed to be based on some of the classical texts such as Qațru al-Ghaist, Al-Sanusiyah, and Jauharat al-Tauhìd (I. Zarkasyi, 1994, p. 3). The main principles of faith explicated in this book can be summarized as follows (I. Zarkasyi, 1994).

With regard to the concept of man in relation to God, men are endowed with four guidances. The first guidance bestowed by Allah to men as to all living creatures is instinct. Since instinct is not enough even for animals, let alone for human beings whose status are nobler than the rest of the creatures, men are equipped with five senses (Al-hawāsul alkhamsu). This second guidance is more extensive and complete than the basic instincts and is enough for the preservation of lives. The five senses can easily be tricked and are prone to misinterpret things. Small things, for example, can barely be 
seen by the eyes and cannot be seen from far, just as big things seem small from faraway. Both guidelines would make a lot of mistakes and misinterpretations if it were not attached to other guidance. Therefore, God bestows the third guidance, namely the mind or the ability to reason. The mind completes the two former guidelines and corrects the mistakes and the misinterpretations of both. Even though the sense of hearing would make many misinterpretations and the sense of seeing is not always accurate, the mind will compensate for all the weaknesses so that the person would know the truth. By using reason, a person is capable of reaching a status higher than the rest of the creatures. By reason men can arrange and organize his life activities to obtain something beneficial for his lives in the world and the hereafter. It is also by knowledge and effort based on reason that one's faith is inculcated. However, according to him it is dangerous to base one's faith only on reason, and therefore one should seek the fourth guidance of Allah to guide him to the right path.

With respect to human need for divine guidance, Imam Zarkasyi introduced a method of proving the existence and the unity of God in such a rational way that student could understand it easily. His argument to prove the unity of God is as follows: If there is more than one God, can one destroy the others? If the answer is positive, then the destroyed one is not God, whereas Allah is the Eternal and can never be destroyed. If one cannot destroy the other then both are not powerful thus are not entitled to be called God, whereas Allah is the Almighty, and the All Powerful. Moreover, if God is more than one, then the creation and the administration of this universe is based on mutual consensus, which implies that one still needs the other. In addition, if that is the case, then both have no real power and strength because of their dependence on one another, 
whereas Allah is the All-Powerful, none are more powerful than Him. Therefore, there can only be one and true God, none are like unto Him and none are co-equal with Him (I. Zarkasyi, 1994, p. 35). He explains more about the Oneness of Allah and His attributes with his attestations from the mind. This book explains his religious theology as he wrote that it is according to the Ahlus-sunnah wal Jamä'ah school of thought that does not rely entirely on reasoning nor prohibits it entirely.

The foregoing theological approach suggests that of Imām Zarkasyi's thought is somewhat similar to that of alAsh'arī school. The Salient feature of al-Ash'arī's school can be summarized at least in two points: first, there is a balance between reason and guidance. Second, argument is based on reasoning and understanding from an objective mind' free from the influence of self-interest, hatred and bias (A. F. Zarkasyi, 2006, p. 33). In a sense, Imam Zarkasyi's intellectual genealogy could be regarded as an adherent of the Salaf theology. It is because he was a student of Mahmud Yunus who graduated from Dārul 'Ulūm, who inclined to the manhaj Salafiyyah. Nurcholis Madjid, one of his disciples commented that Imām Zarkasyi's thought was influenced by manhaj Salafiyyah which was derived from Muhammad 'Abduh:

If ustadz Mahmud Yunus was the first to graduate from Kulliyah Dār-al-'Ulūm in 1931, and had been influenced by the salafiyyah of Muhammad 'Abduh then it is very possible that Imām Zarkasyi was also influenced by the salafiyyah of Muhammad 'Abduh through his teacher. (Nurcholis Madjid, SK Pelita, Thursday, May, 2, 1985).

The above statement seems to be in line with Imām Zarkasyi's own statement: 
Jamāl al-Din al-Afghani and Muhammad 'Abduh struggled together for Islam through politics, though its result was not so maximum. Therefore, Muhammad 'Abduh departed from the orientation of his teacher and chose education as the proper way to struggle for Islam, and the result is more positive. It is because educating people is like preparing a Muslim generation who will spread Islam to all parts of the world. Therefore, I would like to fight for Islam also, continuing the education way, as Muhammad 'Abduh" (A. F. Zarkasyi, 2005, p. 386).

The above statement suggests that Imām Zarkasyi clearly acknowledged that he followed Muhammad 'Abduh's orientation in the field of education, although it is not explicitly stated that he adhered to Abduh's theological thought. However, Amal Fathullah found that there are four similarities between Muhammad Abduh and Imām Zarkasyi in their theological inclinations. First, both are against heretical actions. While Muhammad 'Abduh wrote Risālah Tawhid, Tafsir al-Manār, and many articles in the magazine al-'Urwat al-Wuthqā and al-Manār, Imām Zarkasyi wrote Ushuluddin, and taught his secondary students Tafsìr al-Madrasī, (written by Mahmud Yunus and Umar Bakri), which is the summary of Tafsìr al-Manār, and recommended his university students to read Risālah al-Tawhid.

Second, both agreed to encourage ijtihād and were against Taqlid. Abduh's thought on this point appeared in his Tafsir al-Manār, while Imām Zarkasyi's thought on this point is to be found in his emphasis on the teaching of Arabic language and sciences for his student, which are instrumental for ijtihad like al-Quran and Hadith, Ușul al-Fiqh, Muștalah al-Hadith, Muqāranatal-Madhāhib, and Mubāhathat al-Masāil al-Fiqhiyah. 
Third, they both possessed innovative ideas in reforming the education system. 'Abduh introduced innovations in the teaching method, curriculum and administrative system of Al-Azhar University. He believed that to reform al-Azhar is equal to reforming all Muslims and to destroy it is similar to destroying all Muslims. In other place he states: " My movement is focused on two points. Firstis to fight Taqlid and refer back to the right understanding of Islam from its sources, Al-Quran and Hadith. Second is to use formal Arabic language as an official language (Ridha, 1467, p. 425). In the same manner, Imam Zarkasyi had also carried out educational reform in Indonesia. Fourth, both of them were in agreement on the use of reason for understanding Islam and to keep a balance between the authenticity of Islamic teaching (așālah) and responses to contemporary challenges (mu'assirah) (A. F. Zarkasyi, 2005, pp. 386-387). In short, the theological thought of Imām Zarkasyi is closer to al-Ash'ari school of theology that keeps the balance between Dalill Naqli (revelation) and dalìl 'Aqly (reason), in determining the truth of a particular thing.

Imām Zarkasyi's standpoint regarding the issue of sharia can also be discerned from his position in some legal issues, especially in reference to issues categorized under furū' (branches or subsidiaries matters). His point of view is written on his book Sekedar Penjelasan tentang Masalah Khilafiah (Simple Explanation on the Problem of Differences of Opinions). In this paper Imam Zarkasyi inferred that the matter of dispute among groups of Muslims was only on the subsidiary matters ( $f u r \bar{u}$ ) and not on fundamental matters. Reciting Qunut during Subuh prayer, pronouncing niyyah loudly before every prayer and breaking of fast for the travelers are some examples of the subsidiary matters. 
The source of the dispute, according to Imam Zarkasyi was the lack of understanding of Islam, especially on the differences between the subsidiary ( $f u r u \overline{\text { }}$ ) and fundamental matters (ușūl). In addition, the dispute was also because of their status of being blind follower (taqlid) of a certain ulama or school of thought (I. Zarkasyi, 1984, p. 4). The lack of understanding is clearly evident from the fact that the exponent of reciting the qunut believed that it is the doctrine the school (mazhab) of Ahlussunnah wal Jama'ah, whereas the fact of the matter is that qunut is not a theological but a legal issue. Imam Shafi'i, he exemplified, did not regard qunut as a fundamental doctrine, although, in his Fiqh, he regards qunut as compulsory (I. Zarkasyi, 1984). Imam Zarkasyi wrote in that paper that one day Imām Syāfi'ì travelled to Baghdad. When he became the Imam for the șubuh prayer, he did not read the Qunut, whereas in his Fiqh he regarded it as compulsory. As we know Baghdad was dominated by the Hanafi adherents, who did not deem the qunut as compulsory (wajib) for Subuh prayer. When his disappointed followers asked him, he replied: "it is just to respect them", or to respect the followers of Imam Hanafi.

In Indonesia, in particular and in the Muslim world in general, such a dispute became so serious that one group claims superiority over others. The situation had inspired Imām Zarkasyi to promote the spirit of Islamic brotherhood, through, inter alia the modification of the subject of Fiqh in the curriculum. He also introduced the strategy of teaching Fiqh by holding the principle that student of lower secondary school should not be taught about group conflict in the history of Islam (I. Zarkasyi, 1995, p. 3). However, higher secondary students should be taught comparative schools of jurisprudence, so as to be able to have a broad knowledge 
about the different schools and be prevented from group fanaticism. In this way the students would hopefully understand the meaning of freedom, that is free from taqlid and from group fanaticism. However, he emphasized that to be free one should have broad knowledge first.

\section{His Thought on Modernization}

Having discussed Imām Zarkasyi's religious thought, we shall now discuss his thought on modernization of education. His thought of modernization cannot be comprehended fairly unless it is discerned from his previous experience and impression on traditional Pesantren. Therefore, Imam Zarkasyi's object of modernization refers the condition of traditional pesantren. However, different researchers see the point of modernization from different angles. Amal Fathullah for example mentioned four aspects of modernization namely 1) The method of instruction in general 2) The method of Teaching Arabic and English 3) Strategy of education, consist of religious education, moral education, physical education, entrepreneurship, organizational education, 4) organization and management of education (A. F. Zarkasyi, 2011, pp. 165185). However, Saiful mentions four aspects, namely 1) System and method of education 2) Curriculum material 3) Structure and management of the institution 4) Strategy of changing the mentality or in other words strategy of inculcating the values to the student (Daryaman, 2017, p. 145).

\section{E. His critique of the Pesantren System}

Well-educated in the traditional pesantren Islamic education system, Imām Zarkasyi was fully conversant of its advantages and disadvantages of studying at pesantren, especially its teaching method and curriculum. He criticised 
the teaching method of Arabic language which was found to be inefficient. The students were to learn Arabic grammar (Nahw and Sarf) before they know how to speak. They memorized the grammar but did not understand the meaning of the words and were unable to put the words in a complete sentence. Moreover, in that method the teachers usually translate the Arabic text into native language (Panitia Penulis Riwayat Hidup Dan Perjuangan K.H. Imam Zarkasyi, 1996, pp. 44-45), and as a result students think not in Arabic but in their native languages. Expressing his experience, he stated:
.... I have finished reading Fatḥul Qarīb and Fatḥul Mu'în using the method employed by my teacher, but I did not understand what I have read since I was not allowed to raise any question. If I asked, I could be deemed immoral (sü'ul adab). At last, I thought it is better for me to understand Arabic language first than to read the book. So, why didn't I learn Arabic language first?" (I. Zarkasyi, 1983)

This introspective thought grew into a stronger conviction when Imam Zarkasyi heard the Arabic proverb that nahw and sarf, to the spoken Arabic language is like salt to the food. One can eat food without salt, but cannot eat salt without food (Panitia Penulis Riwayat Hidup Dan Perjuangan K.H. Imam Zarkasyi, 1996, p. 53). So he believed that in studying any language students should not be taught grammar before they are able to speak.

The other aspects of the traditional system criticized by Imām Zarkasyi are the period of study, the curriculum and its evaluation system. In fact, in the old pesantren system there was no specified period of time to finish the study. This is related closely to the curriculum of the pesantren. According 
to Imām Zarkasyi, in the traditional pesantren the curriculum is arranged into three levels of studies. The first level is focused on studying Arabic grammar (nahw, and șarf) and fiqh by using these textbooks: al-Ajrumiyyah, Matan Bina, Fathul $Q a r i \bar{b}$, etc. The second concentrated on al-Sanusi, al-Kailani and Fathul Muin. The third level turns to focus on Kifāyatul 'Awwām, Ummual-Barāhin, Ibnu 'Aqil and other textbooks (Panitia Penulis Riwayat Hidup Dan Perjuangan K.H. Imam Zarkasyi, 1996, p. 46). However, levels are not the same as classes in the modern school system, since there was no formal examination that bound the students to pass from one to another level, except reading the text in front of the kiai. Once the kiai regards a student as being capable of reading and translating the book correctly, he allows the student to read another book or books of another level.

Another weak point of the pesantren curriculum is that all those subjects or books are within the category of religious sciences and no subjects of the so-called 'ulūm fardu kifāyah were taught. Martin describes that the curriculum of traditional pesantren is dominantly religious sciences. The distribution of subjects taught at the Pesantren based on the texts can be categorized into: jurisprudence (fiqh) 20\%; doctrine ('aqìda, uṣul al-dīn) 17\%; traditional Arabic grammar (naḥw, șarf, balāgha) 12\%; hadith collections 8\%; mysticism (tasawwuf, tarīqah) 7\%; morality (akhlāq) 6\%; collections of prayers and invocations, Islamic catechism ( $d u^{\prime} \bar{a}^{\prime}$, wird, mujarrabāt) 5\%; and texts in praise of the Prophets and saints (qișaș al-anbiya, mawlid, manāqib, etc.) 6\% (Bruinessen, 1990, pp. 226-269). The methods of teaching employed for studying those books are also traditional. The most dominant method was the translation method. This method according to Imam Zarkasyi is ineffective, since memorization was preferred over understanding. 
Despite the fact that the traditional pesantren system had some weaknesses, Imam Zarkasyi conceded that it was an effective system to inculcate morality and certain fundamental spirits of Islam such as simplicity (al-basātah), sincerity (alIkhlāș), self-reliance (al-i'timād alā-n-nafsi), Islamic brotherhood (ukhuwwah Islāmiyah) and freedom (al-ḥurriyyah) (I. Zarkasyi, 1965). These spirits could only be inculcated through the boarding system of the pesantren. These advantages of the pesantren system were not available in madrasah system. On the contrary, the positive things about the madrasah, especially its curriculum and method of teaching Arabic language and Islamic sciences could not be found in the pesantren system. In the madrasah, for example, students were able to speak, read and write in both English and Dutch within two years, whereas in the pesantren students cannot speak and write in Arabic during the period of their study (Panitia Penulis Riwayat Hidup Dan Perjuangan K.H. Imam Zarkasyi, 1996, p. 47).

It was from his longstanding experience that Imam Zarkasyi learned the advantages and disadvantages of all systems of Muslim education. From those experiences he desired to integrate the two systems, namely the pesantren and the madrasah systems, into a new system of Islamic education. For the system of formal education, he employed the madrasah system, while for informal and non-formal system of education he took the benefit from the pesantren system.

\section{F. Integrating Two Systems}

With reference to the advantages and disadvantages of two Islamic education systems, namely madrasah and pesantren, Imam Zarkasyi started to evaluate and modified them. On the one hand, madrasah was a good system for formal education like the modern school system, but not sufficient to inculcate 
Islamic values outside the class. On the other hand, pesantren is good system for carrying out non-formal and informal education. Its boarding system could facilitate numbers of activities that enable the inculcation of the way of life and the philosophy of life, but it is not organized systematically.

So, the step taken by Imam Zarkasyi is adopt the positive aspects of both the Madrasah and the pesantren systems and assimilated them within his own system. The nature of the new system is discernible from his statement during the Fifty Years Anniversary of the system (1977) below:

This pondok (pesantren) is an Islamic educational
institution like any other institution. The difference is
only in its teaching method. We use modern teaching
method but do not teach something new in religion.
This pondok (pesantren) is a waqf for the Muslim
ummah and is not the property of the kiai (headmaster
of pesantren) anymore. This pondok is not inclined
to any political party, therefore its motto is Berdiri
di atas dan untuk semua golongan (Stand above and
for all groups). Its educational goal is to produce a
Muslim who has noble character, sound body, broad
knowledge, and independent mind. The final objective
of this pondok is Li i'lä'I kalimatilläh" (I. Zarkasyi,
1976).

The foregoing statement suggested that the point of modernization declared by Imam Zarkasyi are teaching method, waqf system of organization, neutrality of pondok from political party and the goal of education. However, in practice as we will find there are more points that could be regarded as new in pesantren tradition. Commenting on this modernization Karel asserted that Pondok Modern Darussalam Gontor is still deeply rooted in the tradition but has taken a new path (Steenbrink, 1986, p. 14). 


\section{Modernizing Madrasah Curriculum}

One of the advantages of the madrasah system is its curriculum and hence Imam Zarkasyi adopted the curriculum of two modern madrasahs: Madrasah Arabiyah Adabiyyah, Surakarta and the Normaal Islam (Kulliyatul Mu'allimin alIslämiyah), West Sumatera. In fact, before independence there was no standard curriculum for the madrasah. Each madrasah constructed and used its own curriculum. However, the National Conference of Madrasah at Padang in 1936, decided for madrasah in the region of Minangkabau to have a standard curriculum. Even though the two had the same advantages, Imam Zarkasyi named his integrated model as Kulliyatul Mu'allimin al-Islämiyah, following the name of the madrasah founded by Mahmud Yunus (Yunus, 1985, p. 104).

The madrasah curriculum is relevant for Muslim ummah, since Islamic education system in the Muslim world separated religious and secular sciences. This system had resulted in the profile of Muslim scholars who studied religious sciences but know nothing about the social-natural sciences, and those who studied social-natural sciences but had inadequate knowledge of religion. In the modern madrasah, the balance in the curriculum between the religious sciences and the social-natural sciences were maintained. It also employed modern methods of instruction using some tools of teaching like the blackboard or whiteboard, textbooks and chalk or board marker; having examinations, grading systems and the period of study that were never be applied in the traditional pesantren system.

In the curriculum that he adopted from the modern madrasah, Imam Zarkasyi divided the subject into two categories: religious sciences and social-natural sciences. In 
this curriculum the students learn religious subjects such as Al-Quran, Tafsìr, al-Hadīth, Musțalahul Hadīth, al-'Aqā'id, al-Fiqh, Ușūl Fiqh, Tajwìd, etc. as if they were learning at the traditional pesantren (Panitia Penulis Riwayat Hidup Dan Perjuangan K.H. Imam Zarkasyi, 1996, p. 50). For the subject of Tafsir the book used was Tafsìr madrasi and the summary of al-Manār. For al-Hadith he recommended Bulūghul alMarām and Subūl al-Salām, the very books used at traditional pesantren. In order to understand the science of Hadith (Mustalah al-Hadith), the students read Taysir Mustalah alHadith. For the subjects of Fiqh, Imam Zarkasyi composed a book for the lower secondary level, but used al-Fiqh al-Wädih, a text from Egypt for class two until four. To teach the students to be broad-minded in legal issues, Imam Zarkasyi taught the students of class five using Bidāyah al-Mujtahid written by Ibn Rushd.

Fiqih is the subject that would open the students' minds to the fact that differences among the schools of jurisprudence were mostly on the matter of the branches (furu') and not of the fundamental (usul). In addition, this subject was designed to encourage the students to have broad knowledge so as to become mujtahid (a legist formulating independent decision in legal or theological matters), rather than muqallid, or at least to improve the status of one from being muqāllid (imitator) to the status of Muttabi' (follower) (I. Zarkasyi, n.d.-b, p. 24). This subject was also related to the spirit of Islamic brotherhood which has been derailed by Muslim disputes in legal issues, even on the matters of branches or subsidiaries. Those books were taught in Arabic language, after the students had mastered Arabic language. This was perhaps the reason why graduates of the Gontor read, write and speak fluent Arabic language in a relatively short time 
(Panitia Penulis Riwayat Hidup Dan Perjuangan K.H. Imam Zarkasyi, 1996, p. 378; I. Zarkasyi, n.d.-a, pp. 24-26). This curriculum is relevant to Imam Zarkasyi's religious thought delineated above, especially in the field of shariah.

Not only had Imām Zarkasyi modernized pesantren with madrasah curriculum, but also introduced new method of teaching Arabic language. Based on his experience in a few Pesantren, Imam Zarkasyi preferred to teach the students Arabic language before beginning to read Islamic religious textbooks in Arabic. For this he composed Durūs al-Lughah al-'Arabiyyah, for beginners targeting that after completion of this book within one year the students would be able to speak and write Arabic. For the next level he also composed workbook for exercises (Tamrīnāt) and for Arabic Grammar (al-Amthilat al-I'rāb).

In addition to the study of religious sciences, students learn the social-natural sciences such as Mathematics, Biology, Physics, Chemistry, Algebra and Cosmography, Psychology, Sociology and the likes as if they are learning at secular schools. In this new model of curriculum students learn religious subjects with modern teaching method, and study social-natural sciences with religious approaches. The fact was that the teaching of mathematic and arithmetic in this pesantren for example are oriented for the religious purposes, such as for the basis for science of inheritance (farā'id), cosmography ('ilm falaq), for determining the first of Ramadhan, (ilm hisab) arithmetic for calculation in business etc. Imam Zarkasyi is in the opinion that there is no dichotomy of knowledge in Islam, yet reading socialnatural sciences from Islamic perspectives had not been conceptually designed, it anticipates the idea of al-Attas' Islamization of contemporary knowledge. However, Imam 
Zarkasyi's curriculum design is well portrayed by Zuhdi in the following statement:

\begin{abstract}
One of the most notable cases of an educational institution retaining its independence during the introduction of the national curriculum for madrasah was Pondok Pesantren Darussalam Gontor (known as Gontor) in Ponorogo, East Java. The main difference between Gontor and Tebuireng is that Tebuireng separated pesantren education ...from sekolah (school) and madrasah that introduces non-religious knowledge, while Gontor combined the so-called religious and non-religious knowledge in one system. Therefore, when the new (national) curriculum was introduced, Gontor had its own response to the policy (Zuhdi, 2006, p. 422).
\end{abstract}

Zuhdi inference is true for the fact that Imam Zarkasyi did not apply national curriculum, while employing his own curriculum model. It is because, by this curriculum, heintended to produce Muslim scholar (ulama) who are conversant of not only religious knowledge but also social-natural sciences. The ideal output for this system as he reiterated in many occasions was "to produce Ulama with high intellectual capacity and not intellectual who knows little about religion" (Ulama intelek dan bukan intelek yang 'tahu' agama). This implies that he disagrees with any education system that produces scientist or experts in various disciplines but ignorant or know very little about Islam. The implication of Imam Zarkasyi's obsession is quite clear that in the future there should be Muslim scientists who speak about their expertise from Islamic perspectives. In this regard, the modernization of this madrasah curriculum is integrated with the goal of pesantren education that is to produce Muslim scholar (ulama) (Alhamuddin, 2008, pp. 210-211). Therefore, it is erroneous to posit that Imam 
Zarkasyi is in the opinion on the unity of knowledge that there is no different between secular Western knowledge with the Islamic one (Rofiq, 2018, p. 335,340).

With new curriculum system adopted from modern madrasah, Imam Zarkasyi also applied new instructional methods. The principle he maintained was that the method of teaching is more important than the subject taught, however the teacher is more important than the method (al-tariqatu ahammu min al-māddah wa al-mudarrisu ahammu min altarīqah) (Panitia Penulis Riwayat Hidup Dan Perjuangan K.H. Imam Zarkasyi, 1996, p. 119; I. Zarkasyi, n.d.-b, p. 5). To simplify this maxim Imam Zarkasyi used to draw the parable of the knife and the apple. The skill of cutting the apple is more important than the knife, yet knowledge about the skill is not important for someone who is already skillful. So, the personal factor of a teacher is the most important one, and that is the spirit of the teacher (rūh al-mudarris).

All what had been done by Imam Zarkasyi is still relevant to modern education systems. Utomo Infers that when Imam Zarkasyi emphasized the function of language for communication, he is employing an ideology of functionalism in educational method. When Imam Zarkasyi uses the lecture, memorizing, assignment, structured group discussion and self-study methods, he employs the method of fundamentalism of education (Utomo, 2014, p. 70). So, Imam Zarkasyi's effort to modernize the madrasah curriculum was not destructive to madrasah but enrich the system from all angles.

\section{Modernizing Hidden Curriculum}

Observing Imām Zarkasyi's educational practice at Gontor suggested that he seems to believe that curriculum is not only the arrangement of a number of subjects to be 
taught in the class, but also the whole students' activities within the domain of informal and non-formal education. This non-academic curriculum is now called "hidden curriculum" (Meighan, 1981, p. 68). This non-academic curriculum is not offered in madrasah system nor designed in the pesantren system, but in the integration of both systems. The pillars that support this hidden curriculum are the present of Muslim scholar, usually called kiai, and the students usually called Santri, the availability of dormitories and the mosque as the center of activities. Those pillars are very effective in developing the morality and mentality of the students through hidden curriculum. Therefore, there are at least two important points that are prevalent in the pesantren education system: first, Moral and value inculcation; second, mental-skill education.

\section{a. Moral and Value inculcation}

One of the principles of moral education at Darussalam Gontor is that it is not taught by way of teaching (al-Akhlaq la tughrasu bi al-talqin); it is inculcated by way of practice. Imam Zarkasyi taught his students to have four basic characters of morality; they are noble character (good conduct), sound body, broad knowledge and freedom of thought (I. Zarkasyi, 1996, p. 76). However, freedom in this motto is not liberal, but freedom based on Islamic principle or may be interpreted as independent mind which is free to choose the good from the bad. In addition, Imam Zarkasyi also in the opinion that morality can be instilled into the student mind through good example, by establishing moral environment, by providing habitation, by giving advice, creating interest and giving punishment (Karnaen, 2013, p. 76). With regard to character education Nuriz and Awang found that there are similarities between Imam Zarkasyi and al-Zarnuji (Nuriz, 2017, pp. 57-58). 
However, Imam Zarkasyi divided morality into two categories: physical and spiritual morality. The former include gesture, behavior, the way of dressing etc., which mostly deal with social interaction. The latter includes more about the purity of human soul, good character, ethics and others that relates to man-God relation (Fannani \& Zarkasyi, n.d., p. 39). Those two categories of morality are summarized by Imam Zarkasyi in the form of spirit of campus social life, named Five Spirit (Panca Jiwa). The Five Spirits are: Simplicity, Sincerity, Self-Reliance, Islamic Brotherhood, and Freedom. Simplicity is a way of behaving that is applicable to an individual conduct in his or her daily life. This implies that one should live based on his or her basic needs and not on demand, in other words one should not live in luxury life, but a simple one. Sincerity is a principle for work. Imam Zarkasyi in several occasion states that sincerity is the spirit of work (al-ikhlās rūh al-'amal) and quoting the Holy Qur'an suggests that we should follow those who do not ask for salary and they are among the guided people ("QS. Yasin," n.d., v. 21). SelfReliance is an important spirit by which students have to work independently and creatively in solving the problem in the campus. Islamic Brotherhood is an important value inculcated to students for dealing with others, appreciating the differences among them with respect to culture, race, tradition and languages (Baiquni, 2018).

There are, in fact, numbers of values and spirits transformed to the students in this boarding system. These values and spirits are reiterated in various occasion outside the class, pasted in walls of the campus, and written in books, brochure and guide-book of the pesantren. So, the traditional pesantren system of values like that of works, 
morality, social service, brotherhood, life, learning spirits and the likes can be done easily in a favorable environment of pesantren (H. F. Zarkasyi, 2015, pp. 234-237). The variety of students who have different races, cultures and languages that necessitate the act of tolerance is already multicultural education (Zulkarnain, 2016).

All those values or spirits are designed as life conduct in the campus or the basis of all activities. This traditional value are inculcated in the modern way (Nurhakim, 2011). The kiai (Scholar) is the one who consequently applies the spirit in his daily life that worth to be emulated. The inculcation of the spirit of Sincerity, for example, requires no hard effort since the kiai along with senior teachers are dedicating their life for this education sincerely. In addition, those values are also imparted by kiai, the senior teachers, the junior teacher, the senior students and even the students by mean of utterance or verbal expression in the form of speech or written words like a distributed text in all occasion and possible opportunities. So, those values gradually become worldview of the students and code of conduct or morality. Abdullah Syukri Zarkasyi inferred that the philosophy behind this learning strategy is the belief that that a person could be educated not only through reading text, but also through various activities of life. It is like belief (iman) in Islam that should be started from conviction of the heart (bi al-qalbi), declared with the tongue (bi al-lisan), admitted with reason (bi al'aqli), and practiced with all parts of the body (bi-al-Jawarih) (Bahroni, 2012, p. 344). Since all those values are internalized or transformed into the student mind all the time and in all occasion, Ihsan deduces that this could be regarded as similar to Sufi education (Dacholfany, 2015, p. 39). Mu'minah even infers that Imam 
Zarkasyi's idea that emphasizes the importance of moral education is similar to that of Ibn Miskawaih. She even proves that Imam Zarkasyi's Five Spirits has some similarity with Ibn Miskawaih's idea of wasatiyyah. (Mu'minah, 2016, pp. 120-121).

So, the integration of physical and spiritual morality in the form of Five Spirit and other school values is quite effective in building student character and mentality. Asnawir noted that there are correlation between character building and peaceful thinking of students at Darussalam Islamic Boarding School (Asnawir, 2012).This implies that the values inculcated to the students are interrelated and comprehended by the student thoroughly, yet the undeniable fact is that there are students who fail to grasp all those values.

\section{b. Skill Education}

In addition to moral education in the campus life through various ways, Imām Zarkasyi designed a hidden curriculum with the objectives of inculcating mental skill, since it is more important than job skill (Panitia Penulis Riwayat Hidup Dan Perjuangan K.H. Imam Zarkasyi, 1996, p. 62). This idea seems to be an attempt to change the mentality of Indonesian society that oriented their education for becoming government servant, as he says:

Our education now is oriented mostly to the produce government servants, and this has influenced deeply the orientation of the youth. We do not understand whether it is the remnant of colonialism or feudal education (Panitia Penulis Riwayat Hidup Dan Perjuangan K.H. Imam Zarkasyi, 1996, p. 371). 
He also asserts that: "Some believe that being a government servant is a good job, because the work is not so hard but one could get a good salary. It is blind fanaticism or blind belief, since people have no experience with other jobs." (Sahal \& Zarkasyi, 1993, p. 4) This implies that the obsession of becoming government servants is real in Indonesian society.

Imām Zarkasyi strictly in the opinion that the true Islamic education should be directed towards worship (ibadah), seeking knowledge (talab al-'ilmī) and not for becoming government servant (Imam. Zarkasyi, n.d.-a, p. 4). Therefore, Zarkasyi did not encourage the student to rely on certificate and instead he inculcated the spirit of self-reliance (al-i'timād 'alā an-nafsi), one of the spirits of the pesantren. To him becoming an entrepreneur who manages his own business and employs many officers is better than becoming officer. Lance Castle also notes that instead of teaching job skill, Imam Zarkasyi educates the student life skill with creativity and high morality (Castles, 1966, pp. 30-31).

The strategy of inculcating the spirit of entrepreneurship is by involving all students in the extramural activities. The students are given the responsibility to manage their own activities under the umbrella of Student Organizations. The organizations which are under the guidance of senior teachers, now has 21 departments involving 312 staffs with 4000 members (Tim Redaksi, 2009, p. 9). The head of Student Organization is elected by the students through the process of syura. The guiding principle in this organization is that everyone should be "ready to lead and ready to be led" sincerely based on the spirits of the 
pesantren. Therefore, in the election of its chairman there is no political nuance, vested interest, political campaign and an ambitious individual.

Beyond the structure of the student organization, there are dormitories organizations involving many staffs such as the scout movement, sport club, public speaking club, English/Arabic club and city-based club. In these optional activities each student is free to choose his activity according to his interest, talent and preference. This implies that those who are not involved in student organizations still have opportunities in other organization. As a result, from early morning of Subuh prayer until ten a clock at night, all students are preoccupied with activities. The secret of this refers to the teaching of Imam Zarkasyi that young men should be kept busy and should not be free from any meaningful activities (farāgh). He reiterates the saying that "Break or rest is no other than shifting from one activity to another".

All these organizations and clubs are quite instrumental for inculcating the mental skill to students. Hafid Hardoyo's research suggested that Darussalam Gontor had effectively applied four interaction of Meghan's theory of hidden curriculum, namely generalization, modeling, explication and reward and punishment (Hardoyo, 2009, pp. 308-310). Mardiyah also found that the term "learning by doing" that was frequently mentioned by Imam Zarkasyi is no other than learning society standardized by UNESCO as the principle of education where society are learning to know/think, learning to do, learning to live together and learning to be (Mardiyah, 2012, p. 83). Imroatul Fatihah, Zuli Dwi Rahmawati and Najwa found that 
Gontor education produces leaders in society. Najwa summarized the transformation of leadership skills to the student in ways that can be in 7P: Pengarahan (direction), Pelatihan (training), Penugasan (giving task), Pembiasaan (habituation), Pengawalan (supervision), Pemberian teladan (giving role model) and Pendekatan (approach) (Fatihah, 2018; Mu'minah, 2016).

\section{Modernizing the Institutional system.}

As was mentioned above, one of the modernization points taken by Imam Zarkasyi is pesantren organization. This step is taken since he realized that the traditional pesantrens were plagued with stagnancy and ineffective institutional management due to its status as property of an individual or family. Since the traditional pesantren is owned by kiai and his family, its sustainability is unwarranted. It is because when the kiai is died he would be substituted by his son or son-inlaw and so on. However, when there is no family member who could succeed the kiai the pesantren would cease to operate. This is the weak point of pesantren organization that does not ensure the sustainability of pesantren. To resolve this drawback, in 1958 Imam Zarkasyi with his two elder brothers omitted this tradition by endowing the pesantren and all the land inherited from their parents to the Muslim ummah. Consequently, the pesantren was no longer the individual property of the founders or their descendants. They chose 15 persons as member of Waqf Board declaring in written that after the dead of the founders they should be responsible for the succession of pesantren leadership. Another point of the declaration asserted that the pesantren should be developed further to qualify as an Islamic university that offers its service to the ummah (Piagam Penyerahan Wakaf Pondok Modern 
Gontor, 1958). By this step the dead of the kiai would not give any impact on the leadership of pesantren, and thus its sustainability is ensured. Utomo infers that the mostsignificant modernization of pesantren education designed by Imam Zarkasyi is the dimension of education management, which is diametrically at variance with conventional management of traditional pesantren (Utomo, 2014, p. 71). Bukhory comments that the creation of Waqf Board as the highest authority at Gontor on the one hand reduced the leadership system of traditional pesantrens which are generally inherited from kiai to his son or son in law and so on, yet on the other hand it warrants the sustainability of pesantren in the future (Bukhari, 2017, pp. 266-272).

This reformative step was considerably effective, since after the death of Imam Zarkasyi in 1985, the Waqf Board had played significant role in the succession of kiai. The pesantren has survived well and has been properly maintained, and its property had been successfully developed. Now the pesantren has no less than 27 business enterprises in various sectors such as bookshops, pharmacy, food industry, rice field, mini market, radio station, magazine, restaurant, forest and the likes. The pesantren has about 25 branches throughout Indonesia and its system had been developed and modeled by its graduate in about 400 pesantren. From secondary level of education, the pesantren is now developed its higher education named University of Darussalam.

\section{G. Conclusion}

Following the aim of this research, we have so far delineated the thought of Imam Zarkasyi in modernizing traditional pesantren with special emphasis on three pivotal aspects of pesantren namely: educational, curricular and 
institutional system. The way Imam Zarkasyi modernizes educational system is by adapting Islamic school or madrasah system and integrating it with the environment of traditional system of pesantren. The students or the santri live in their dormitory as their home, and study at the classroom employing modern method of teaching and learning. In modernizing the curricular system Imam Zarkasyi integrates madrasah curriculum with that of traditional pesantren and as a result students learn both general sciences and religious subjects. However, learning a lot of subjects might be burden for students who are intellectually weak, but environment might help the student learn better. It is because Imam Zarkasyi also modernize the environment of pesantren to be worthy for learning and for the inculcation of the traditional values of pesantren. All the time and all activities at pesantren are designed for the process of mental training, moral education and other value inculcation. Therefore Imam Zarkasyi reiterates in different occasions that "all what you see, you hear, you experience at Gontor are for the sake of education". Finally, for the institutional modernization the conversion of pesantren from personal or family into public property by way of waqf or endowment is strategic step for sustainability of pesantren and for the warranty of leadership succession. Be that as it may, those steps of modernization, especially in its formal education or madrasah system, require continuous reformation or renewal. It is because madrasah as a system of Islamic education, since Indonesian independence until now, had undergone significant change and development in so different aspects that students of madrasah could compete with the achievement of those of modern school. (Abdullah, 2019, 96). 
In response to this modernization certain people in society were reluctant to admit Darussalam Gontor as pesantren in traditional sense. Another part of society regarded it as simply Islamic boarding school. The society could be true, since it is no longer traditional pesantren for it applied modern system of education, yet it can still be called pondok or pesantren because, as the inference of Hamid Fahmy it maintains the spirits of pesantren tradition in the real sense of the words (H.F. Zarkasyi, 2015, 223-248). So this is neither traditional pesantren nor boarding school, the middle way is to admit the epithet given by those who frequently visit this pesantren, namely "Modern Pondok" which subsequently become formal name, Pondok Modern Darussalam. Lance Castle illustrated this modern pesantren as "....genuinely Indonesian, but at the same time both modern and Islamic". However, looking at the latest development of this modern pesantren, society starts looking it as a well-constructed society for imparting knowledge, morality, values, and various skills of life and appreciatively gave another epithet that this is "school of life".

\section{REFERENCES}

Abdullah, Mukhammad, "School Culture ToServe Performance Of Madrasah In Indonesia”, Qudus International Journal Of Islamic (QIJIS) Studies Volume 7, Number 1, 2019, 98.

Alhamuddin. (2008). Pendidikan Islam Modern ala Trimurti Pondok Modern Darussalam Gontor. At-Ta'dib, 3(2). https://doi.org/http://dx.doi.org/10.21111/at-tadib. v3i2.566.

Alhamuddin, Fahmi Fatwa Rosyadi Satria Hamdani, "Hidden Curriculum: Polarisasi Pesantren Dalam Upaya 
Membentuk Kesalehan Individu Dan Sosial", (Case Study Pondok Modern Darussalam Gontor Ponorogo, AlMurabbi Vol. 5, No. 1, Juli 2018: 2540-7619.

Asnawir, A. (2012). The Correlation Between Character Building and Peaceful Thinking of Students at Darussalam Islamic Boarding School in Ponorogo, East Java. Al-Ta Lim, 19(2), 93. https://doi.org/10.15548/ jt.v19i2.11.

Bahroni, I. (2012). Streamlining Education Institution Through Waqf Enlargement: An Experience of Gontor System. At-Ta'dib, 7(2). https://doi.org/http://dx.doi. org/10.21111/at-tadib.v7i2.79.

Baiquni, M. M. (2018). Panca Jiwa Pergerakan Reformasi Pendidikan KH.Raden Imam Zarkasyi Pondok Modern Darussalam Gontor. Rahmatan Lil Alamin, Journal of Peace Education and Islamic Studies, 1(1).

Bruinessen, M. (1990). Kitab kuning; Books in Arabic script used in the Pesantren milieu; Comments on a new collection in the KITLV Library. Bijdragen Tot de Taal-, Land- En Volkenkunde / Journal of the Humanities and Social Sciences of Southeast Asia, 146(2), 226-269. https://doi.org/10.1163/22134379-90003218.

Bukhori, U. (2017). “KH. Imam Zarkasyi Dan Genre Baru Pondok Pesantren. Dirosat: Journal of Islamic Studies, 1(2), 259. https://doi.org/10.28944/dirosat.v1i2.21.

Castles, Lance, (1966). Notes on the Islamic School at Gontor. Indonesia, 1.

Dacholfany, M. (2015). Pendidikan Tasawuf di Pondok Modern Darussalam Gontor. Nizham Journal of Islamic Studies, 3(2), 27-42. Retrieved from http://e-journal. metrouniv.ac.id/ index.php/nizham/article/view/894. 
Dacholfany, M. Ihsan, “Leadership Style in Character Education at The Darussalam Gontor Islamic Boarding, Al-Ulum Volume 15 Number 2 December 2015 Page 447 - 464.

Daryaman, S. M. (2017). Modernisasi Pendidikan Pesantren di Indonesia ( Studi Pemikiran K.H. Imam Zarkasyi ). Jurnal Penelitian Pendidikan Islam, 5(2), 57-70.

Dasuki, H. (1960). Sejarah Pondok Modern Gontor (1st ed.). Ponorogo: Gontor Press.

Dhofier, Z. (1982). Tradisi pesantren: studi pandangan hidup Kiai dan visinya mengenai masa depan Indonesia. Jakarta: Lembaga Penelitian, Pendidikan, dan Penerangan Ekonomi dan Sosial Jakarta.

Fannani, Z., \& Zarkasyi, I. (n.d.). Sendjata Pengandjoer dan Pemimpin Islam. Ponorogo: Trimurti Press.

Fatihah, I. (2018). Kepemimpinan KH. Imam Zarkasyi Di Pondok Modern Darussalam Gontor. Journal of Islamic Education Management, 2(2).

Hardoyo, H. (2009). Kurikulum Tersembunyi Pondok Modern Darussalam Gontor. At-Ta'dib, 4(2).

Iqbal Fasa, Muhammad "Gontor As The Learning Contemporary Islamic Institution Transformation Toward The Modernity", Hunafa: Jurnal Studia Islamika, Vol. 14, No. 1, Juni 2017 : 141-174.

Karnaen, A. (2013). The Policy of Moral Education on KH Imam Zarkasyi's Thought at Gontor Modern Islamic Boarding School. Jurnal Pendidikan Islam, 3(1), 163. https://doi. org/10.14421/jpi.2014.31.163-182.

Koentjaraningrat. (1982). Ikhtisar Sejarah Pendidikan di Indonesia: Masalah-masalah Pendidikan di Indonesia. Jakarta: Lembaga Penelitian, Pendidikan, dan Penerangan Ekonomi dan Sosial Jakarta. 
Mardiyah, M. (2012). Kepemimpinan Kiai dalam Memelihara Budaya Organisasi di Pondok Modern Gontor , Lirboyo Kediri, dan Pesantren Tebuireng Jombang. TSAQAFAH, 8(1), 67. https://doi.org/10.21111/tsaqafah.v8i1.21.

Meighan. (1981). A Sosiology of Education. London: Holt Rinehart and Winston.

Mu'minah, N. (2016). Character Building Dalam Konsep Pendidikan Imam Zarkasyi Ditinjau Dari Filsafat Moral Ibnu Miskawaih. Jurnal Filsafat, 25(1), 100. https://doi. org/10.22146/jf.12616.

Mughni, S. A. (2013). Pemikiran K.H. Abdul Wahid Hasyim Tentang Pembaharuan Pendidikan Islam. Universitas Islam Negeri Syarif Hiidayatullah Jakarta.

Mulyasari, Ari, (2016) Konsep Pendidikan Pondok Modern Dalam Perspektif KH.Imam Zarkasyi, Thesis Presented for partial fulfillment for the degree of Bachelor of Art in Islamic Education, Universitas Islam Negeri Syarif Hidayatullah, Jakarta, 31-62.

Najwa Mu'minah, Character Building Dalam Konsep Pendidikan Imam Zarkasyi Ditinjau Dari Filsafat Moral Ibnu Miskawaih, Jurnal Filsafat, Vol. 25, No. 1, Februari 2015: 100-133.

Nurfadilah, A. (2019). Madrasah Nizamiyah: Peranan Kh. Abdul Wahid Hasyim Dalam Pembaharuan Pendidikan Islam Di Pesantren Tebuireng (1934-1953). Universitas Pendidikan Indonesia Bandung.

Nurhakim, M. (2011). Imam Zarkasyi dan Pembaharuan Pesantren : Rekonstruksi Aspek Kurikulum, Menejemen dan Etika Pendidikan. PROGRESIVA, 5(1).

Nuriz, M. Adib Fuadi \& Jaffary Awang , “Character Education: Study of Burhanuddin Al-Zarnuji and Imam Zarkasyi's 
Thought", Jurnal Sultan Alauddin Sulaiman Shah, Vol.4 BIL 1 (2017).

Panitia Penulis Riwayat Hidup Dan Perjuangan K.H. Imam Zarkasyi. (1996). Biografi KH. Imam Zarkasyi Dari Gontor Merintis Pesantren Modern. Ponorogo: Gontor Press.

Piagam Penyerahan Wakaf Pondok Modern Gontor (1958). Indonesia.

QS. Yasin. (n.d.). In Quran.

Purnama, (2013) Medina Nur Asyifah, Transformasi Pendidikan Islam, Perspektif KH.Imam Zarkasyi Dalam Pengembangan Pesantren Modern Gontor, Thesis Program Studi Magister Pendidikan Agama Islam, Sekolah Pascasarjana, Universitas Islam Negeri, Maulana Malik Ibrahim Malang, 100-128.

Ridha, M. R. (1467). Târîkh Ustâdz al-Imâm al-Syaikh Muhammad Abduh. Egypt: Dar Al-Manarah.

Rofiq, A. C. (2018). Perspektif K.H. Imam Zarkasyi Mengenai Kesatuan Ilmu Pengetahuan. Ta'allum: Jurnal Pendidikan Islam, 6(2). https://doi.org/10.21274/ taalum.2018.6.2.313-346.

Sahal, A., \& Zarkasyi, I. (1993). Pengarahan Rihlah Iqtisadiyah Siswa Kelas Enam KMI Gontor. Ponorogo: Darussalam Press.

Steenbrink, K. A. (1986). Pesantren, madrasah, sekolah: pendidikan Islam dalam kurun moderen. Jakarta: Lembaga Penelitian, Pendidikan dan Penerangan Ekonomi dan Sosial. Retrieved from http://catalog. hathitrust.org/api/volumes/oclc/15218103.html.

Tim Redaksi. (2009). Wardun, Warta Dunia Pondok Modern Darussalam, Tahun Ajaran 2008-2009. WARDUN.

Utomo. (2014). Pemikiran Pendidikan K.H. Imam Zarkasyi. Jurnal Didaktika Islamika, 3(1). 
Yapono, Abdurrahim, "Filsafat Pendidikan dan Hidden Curriculum dalam Perspektif KH. Imam Zarkasyi (19101985)", Tsaqafah Vol. 11, No. 2, November 2015, 291-312; htp://ejournal.unida.gontor.ac.id/index.php/tsaqafah.

Yuliati, Kadar, Kaderisasi Kepemimpinan di Pondok Modern Darussalam Gontor Ponorogo Jawa Timur, Tesis Magister, Universitas Islam Negeri, Yogyakarta, 2015.

Yunus, M. (1985). Sejarah Pendidikan Islam. Jakarta: Hidakarya Agung.

Zarkasyi, A. F. (2005). Konsep tauhid Ibn Taymiyyah dan pengaruhnya di Indonesia: kajian kes terhadap penggubalan kurikulum pengajian akidah di pondok modern Darussalam Gontor Ponorogo Indonesia. Kuala Lumpur: Jabatan Akidah dan Pemikiran Islam, Akademi Pengajian Islam, Universiti Malaya.

Zarkasyi, A. F. (2006). Ilmu-l-Kalam: Taarikh-al-Madzahib alIslamiyyah wa Qadlayaha al-Kalamiyyah. Ponorogo: Darussalam University Press.

Zarkasyi, A. F. (2011). "Tajdid al-Fikri al-Tarbawi al-Islami Inda alShaikh Imam Zarkasyi". Journal of Indonesian Islam, 5(1), 153. https://doi.org/10.15642/JIIS.2011.5.1.153-191.

Zarkasyi, H. F. (2015). "Modern Pondok Pesantren: Maintaining

Tradition in Modern System". TSAQAFAH, 11(2), 223. https://doi.org/10.21111/tsaqafah.v11i2.267.

Zarkasyi, I. (n.d.-a). Diktat Pekan Perkenalan. Ponorogo: Darussalam Press.

Zarkasyi, I. (n.d.-b). Pedoman \& Arah Tiap-tiap Pelajaran Pada Tiap-tiap Kelas. Ponorogo: Darussalam Press.

Zarkasyi, I. (1965). Panca Jiwa Pondok Pesantren. In Konggres Umat Islam. Yogyakarta. 
Zarkasyi, I. (1976). Pidato pada Resepsi Kesyukuran Setengah Abad Pondok Modern Darussalam Gontor dan Peresmian Masjid Jami' Gontor. Ponorogo.

Zarkasyi, I. (1983). Transkip Pengarahan Dalam Acara Fathul Kutub Siswa kelas VI KMI Pondok Modern Gontor. Ponorogo: Darussalam Press.

Zarkasyi, I. (1984). Sekedar Penjelasan tentang Masalah Khilafiyah. Ponorogo: Gontor Press.

Zarkasyi, I. (1994). Ushuluddin, 'Ala Madzhab Ahli-s-Sunnah wa-l-Jamā'ah. Ponorogo: Trimurti Press.

Zarkasyi, I. (1995). Pelajaran Fiqh 1. Ponorogo: Trimurti Press.

Zarkasyi, I. (1996). Anakku Jadilah Pemuda Pejuang. Bulletin IKPM.

Zuhdi, M. (2006). Modernization of Indonesian Islamic schools' curricula, 1945-2003. International Journal of Inclusive Education, 10 (4-5), 415-427. https://doi. org/10.1080/13603110500430765.

Zulkarnain, F. (2016). The Thought of KH Imam Zarkasyi on Multicultural Education at Modern Islamic Boarding School Gontor Ponorogo. Jurnal Pendidikan Islam, 2(1), 67. https://doi.org/10.15575/jpi.v2i1.694. 